\title{
A Sight "Fearfully Grand"-Eruptions of Lassen Peak, California, 1914 to 1917
}

$\mathrm{O}$ n May 22, 1915, a large explosive eruption at the summit of Lassen Peak, California, the southernmost active volcano in the Cascade Range, devastated nearby areas and rained volcanic ash as far away as $\mathbf{2 8 0}$ miles to the east. This explosion was the most powerful in a series of eruptions during 1914-17 that were the last to occur in the Cascade Range before the 1980 eruption of Mount St. Helens, Washington. A century after the Lassen eruptions, work by U.S. Geological Survey (USGS) scientists in cooperation with the National Park Service is shedding new light on these events.

Lassen Peak in Lassen Volcanic National Park, northern California, is the largest of a group of more than 30 lava domes erupted in that area during the past 300,000 years. These steep-sided accumulations of volcanic rock were created by the pushing up of lava too viscous to flow away from its source. Eruptions 27,000 years ago formed Lassen Peak, probably within a period of only a few years. Standing more than 2,000 feet $(600 \mathrm{~m})$ above its surroundings and having a volume of half a cubic mile $\left(2 \mathrm{~km}^{3}\right)$, it is one of the largest lava domes on Earth.

When Lassen Peak formed, it must have looked much like the nearby 1,100-year-old Chaos Crags domes do today, with steep sides covered by angular rock talus. However, from 25,000 to 18,000 years ago, Lassen's shape was significantly altered by glacial erosion. For example, the bowl-shaped depression on the volcano's northeastern flank was eroded by a glacier that extended out 7 miles $(11 \mathrm{~km})$ from the dome. Today, one tiny remnant of a glacier survives in a hollow on Lassen's eastern flank.

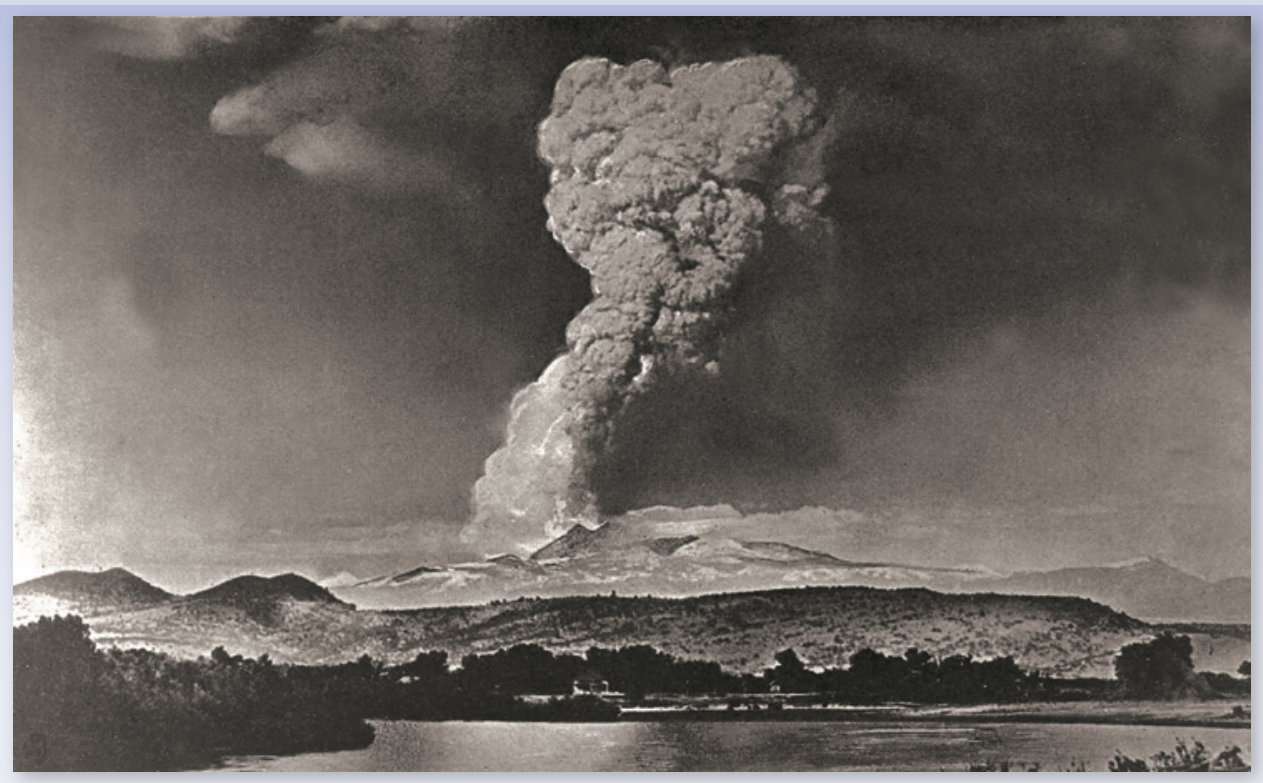

Lassen Peak in northern California produced a series of eruptions during 1914-17. The largest of those eruptions, on May 22, 1915, blasted rock fragments and pumice high into the air and rained fine volcanic ash as far away as Elko, Nevada, 280 miles ( $450 \mathrm{~km}$ ) to the east. This photograph, taken from the town of Red Bluff, 40 miles $(65 \mathrm{~km})$ west of the volcano, shows the huge eruption column of ash and gas, which rose to a height of more than 30,000 feet $(9,000 \mathrm{~m})$. (Photograph by R.E. Stinson; courtesy of the National Park Service.)

The 1914-17 eruptions of Lassen Peak were among the first volcanic events to occur after photography became readily available to amateurs. Thus, they were documented and popularized by the northern California media, primarily the San Francisco Chronicle, and subsequently by the popular scientific media. A variety of accounts and interpretations of the eruptions were published in the years shortly after they occurred. Most of these accounts are flawed because of scientists' lack of experience studying volcanoes at that time, failure to recognize crucial evidence in the deposits, and misinterpretation of eruption photographs. In recent decades, significant advances have been made in volcanology research, and these have enabled U.S.
Geological Survey (USGS) and other scientists to piece together a more accurate understanding of the events surrounding the Lassen Peak eruptions of 100 years ago.

\section{Initial Rumblings}

On May 30, 1914, Lassen Peak awoke from a 27,000-year-long slumber when it was shaken by a steam explosion. Such steam blasts occur when molten rock (magma) rises toward the surface of a volcano and heats shallow groundwater. The hot water then rises under pressure through cracks and, on nearing the surface, vaporizes and may vent explosively. That first explosion created a small crater at the summit of Lassen Peak, and each of more

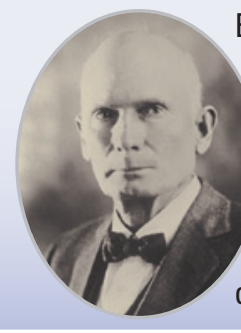

Benjamin Franklin Loomis (1857-1935) was a local businessman, Lassen Park supporter, and amateur photographer. Loomis used an $8 \times 10$-inch view camera with glass-plate negatives. He set up a portable darkroom in a tent and made his own film by applying the silver emulsion to the glass plates just before exposing them. Many photographers recorded the Lassen Peak eruptions and their effects, but Loomis left the most complete and best documented photographic record of the events. Excited at seeing Lassen Peak erupt on June 14, 1914, Loomis wrote, "The sight was fearfully grand." Many of his images were published in his book "Pictorial History of the Lassen Volcano" (1926, republished by the Lassen Association, 110 p.), and many of the original glass plates now reside in the archives of the National Park Service. Loomis took most of the historical pictures used in this Fact Sheet, and several of his photographs proved crucial to understanding the chronology and processes of the May 1915 eruptions. 


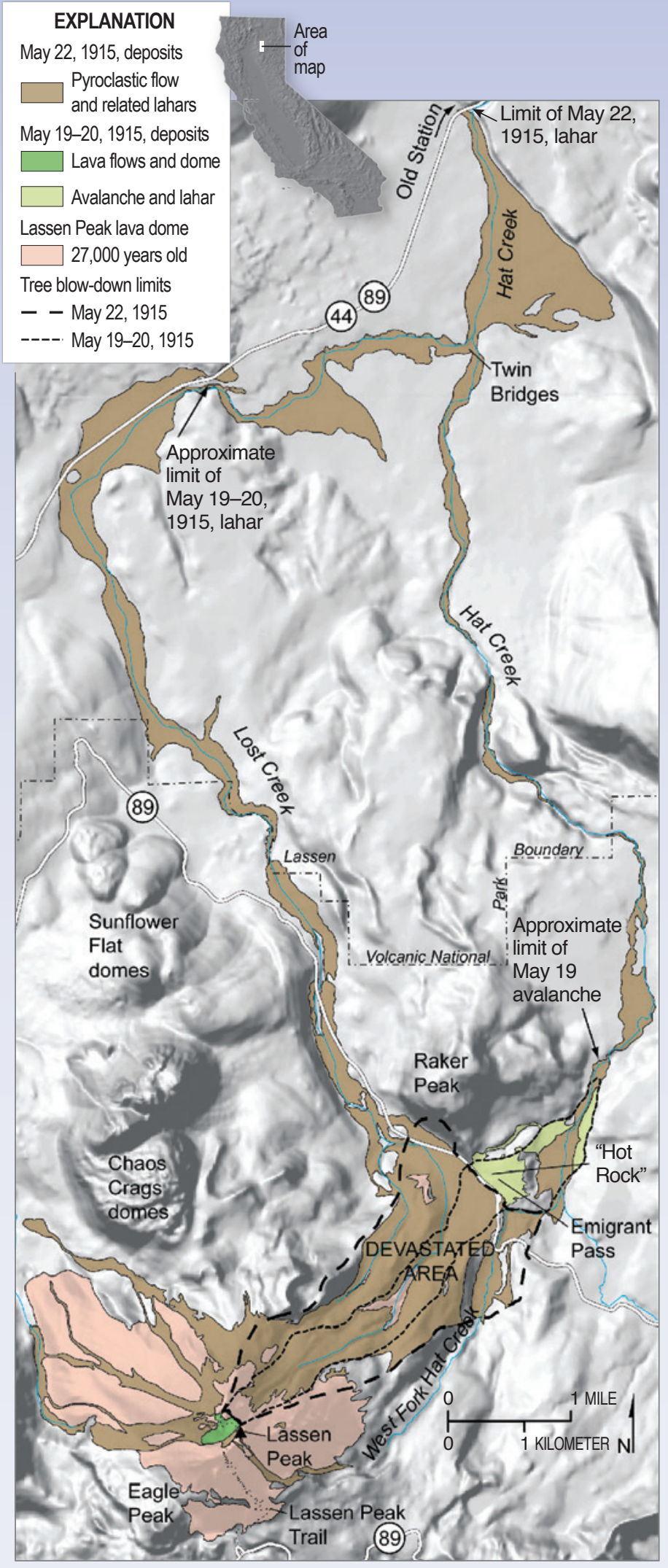

On May 22, Lassen Peak exploded again in a powerful climactic eruption that blasted rock fragments and pumice high into the air, creating the larger and deeper of the two craters seen at the summit of the volcano today and generating a vertical eruption column that rose to 30,000 feet $(9,000 \mathrm{~m})$. Partial collapse of the eruption column generated a high-speed avalanche of hot ash, pumice, rock fragments and gas, called a pyroclastic flow, that swept down the northeast side of the volcano. Trees still standing after the May 19 eruption were now blown down. The pyroclastic flow rapidly melted snow in its path, creating a lahar that followed the path of the lahar 2 days earlier and rushed down Lost and Hat Creeks to Old Station, releasing water that again flooded lower Hat Creek Valley. than 180 subsequent steam explosions enlarged it. Over more than 11 months, these steam explosions blasted out a crater 1,000 feet $(300 \mathrm{~m})$ long.

In mid-May 1915, the character of the eruption changed dramatically. On the evening of May 14, 1915, incandescent blocks of lava could be seen bouncing down the flanks of Lassen Peak from as far away as Manton, 20 miles $(32 \mathrm{~km})$ to the west. By the next morning, a growing dome of dacite lava (dacite contains 63 to 68 percent silica $\left.\left[\mathrm{SiO}_{2}\right]\right)$ had welled up and filled the crater at the summit of Lassen Peak.

\section{Events of May 19-20, 1915}

Late on the evening of May 19, a large explosion shattered the dacite dome, creating a new crater at the summit of Lassen Peak. No new magma was ejected in this explosion, but glowing blocks of hot lava from the dome fell on the summit and the deeply snow-covered upper flanks of Lassen Peak - the winter of 1914-15 was the first recorded El Niño year in the western United States, and more than 30 feet $(9 \mathrm{~m})$ of snow blanketed the upper flanks of Lassen Peak. These falling blocks of hot rock launched a half-mile-wide avalanche of snow and rock that roared 4 miles $(6.5 \mathrm{~km})$ down the volcano's steep flank and over a low ridge at Emigrant Pass into Hat Creek (see map).

As the hot lava blocks broke into smaller fragments, the snow melted, causing the avalanche to transform into a giant mudflow of volcanic materials, called a lahar. The bulk of this lahar was deflected northwestward at Emigrant Pass and flowed another 7 miles $(11 \mathrm{~km})$ down Lost Creek. As they came to rest, both the avalanche and lahar released huge volumes of muddy water, flooding the lower Hat Creek Valley during the early morning hours of May 20. The flood damaged several ranch houses in the Old Station area. Fortunately, the few people in these houses escaped with only minor injuries. The flood continued down Hat Creek more than 30 miles $(48 \mathrm{~km})$ to the Pit River, where many fish were killed by the muddy water.

Also during the night and early morning of May 19-20, dacite lava, somewhat more fluid than that erupted during the previous week, welled up into and filled the new crater at Lassen Peak's summit. It spilled over low spots in the crater rim and flowed as two separate lobes 1,000 feet $(300 \mathrm{~m})$ down the steep west and northeast flanks of the volcano. 


\section{DEVASTATION CAUSED BY THE MAY 1915 ERUPTIONS}

Sequence of photographs taken by B.F. Loomis before and after the cataclyscmic eruptions of Lassen Peak in May 1915.
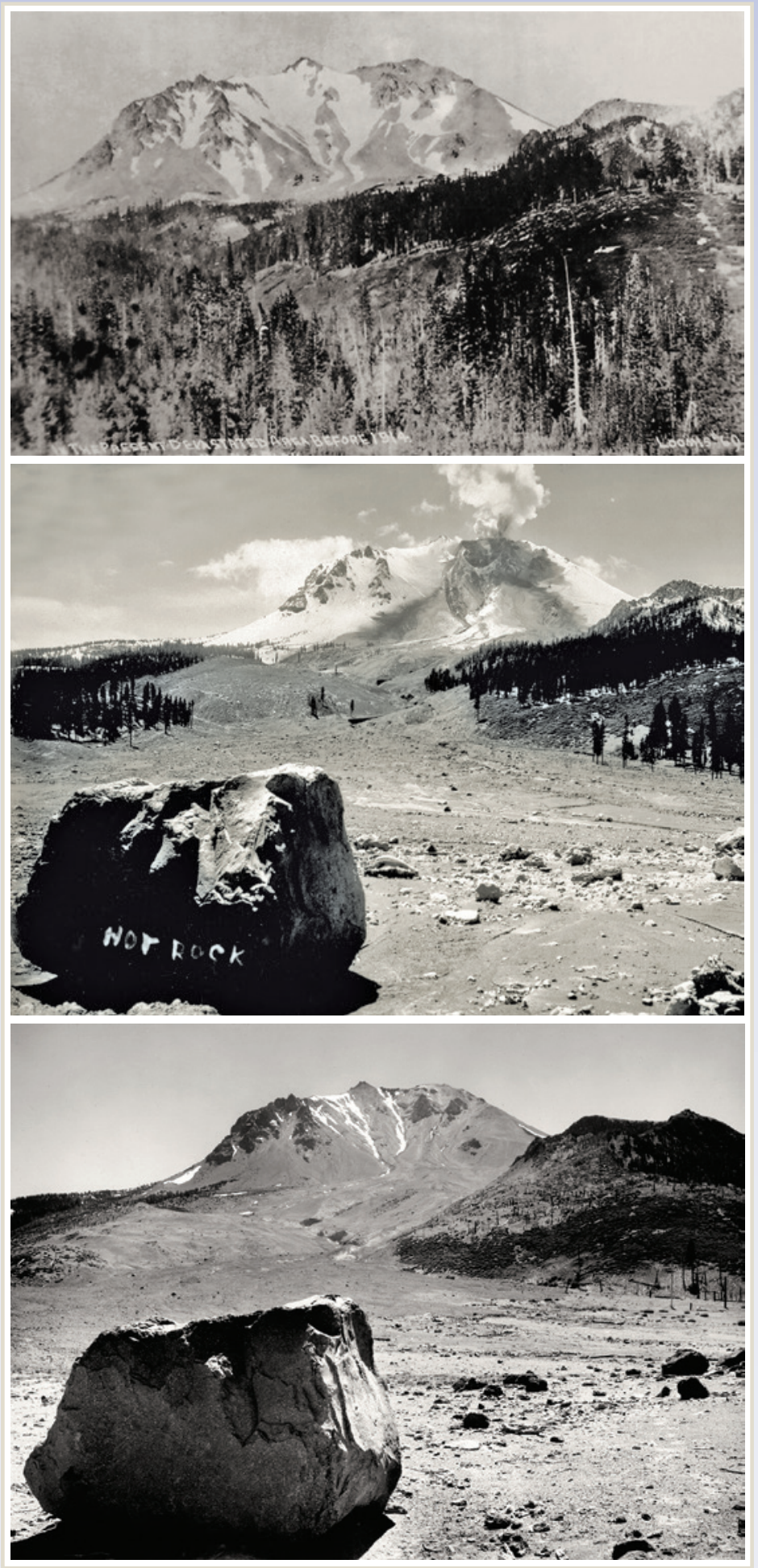

Middle: View taken at noon on May 22,1915 , showing the destruction from the avalanche and lahar of May 19-20. Trees 100 feet $(30 \mathrm{~m})$ tall were uprooted and carried away with ease. The large rock in the foreground, labeled "hot rock" by Loomis, is a piece of the lava dome that filled the crater during the previous week that was carried down by the avalanche. Note the remaining tree-covered slopes at the left and right margins of the avalanche path and the dark gray tongue of new dacite lava below the volcano's summit. That lava erupted on the night of May 19-20.

Bottom: View of Lassen Peak's northeast flank taken in June 1915, showing the full devastation caused by the cataclysmic explosive eruption of May 22. Trees still standing on the morning of that day were blown down or snapped off and their trunks left lying on the ground, pointing away from Lassen Peak. The lava flow below the summit is gone, and the May 22 mudflows have smoothed the surface of the May 19 avalanche and lahar deposit. The "hot rock" remains - and can still be seen today on the Devastated Area Interpretive Trail. The appearance of the Devastated Area changed little for 50 years as seedlings struggled to gain a foothold. Today, however, young vigorously growing trees are obscuring the devastation and reclaiming the area as forest.

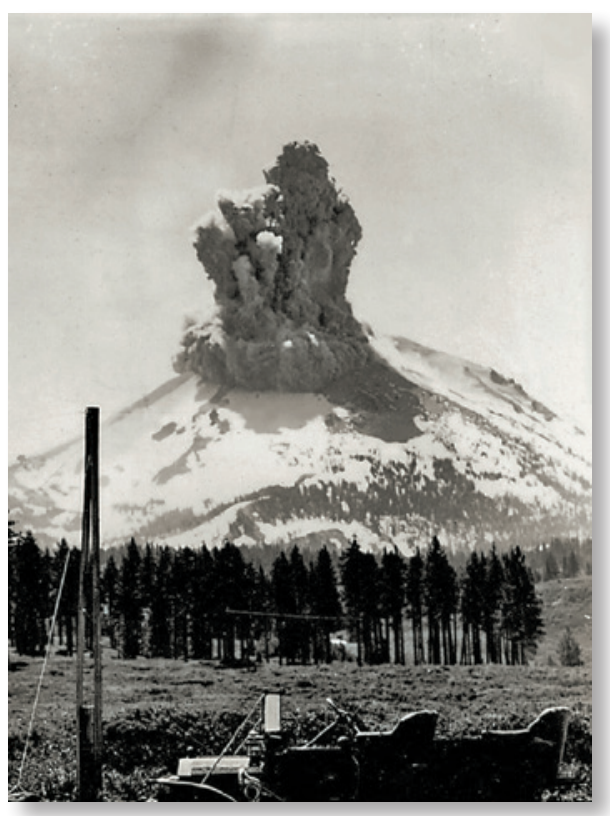

A steam-explosion eruption at Lassen Peak on June 14, 1914. Such steam-blast eruptions ranged from a few minutes to several hours in duration and often sent plumes thousands of feet above the volcano. Photograph taken by B.F. Loomis from a point west of Manzanita Lake, about 6 miles $(10 \mathrm{~km})$ from Lassen Peak.

\section{Climactic Event of May 22, 1915}

After two quiet days, Lassen Peak exploded in a powerful eruption at about 4:00 in the afternoon of May 22. That blast hurled rock fragments and pumice high into the air and created the larger and deeper of the two craters seen today near the summit of the volcano. Over the next 30 minutes, a huge column of volcanic ash and gas rose more than 30,000 feet $(9,000 \mathrm{~m})$ into the air-it was visible from as far away as Eureka, California, 150 miles $(240 \mathrm{~km})$ to the west. Partial collapse of the eruption column that fell onto the northeastern slope of Lassen Peak generated a high-speed flow composed of hot ash, pumice, rock fragments, and gas - called a pyroclastic flow - that swept down the side of the volcano, devastating an area of 3 square miles $\left(7.5 \mathrm{~km}^{2}\right)$. This flow rapidly incorporated and melted snow in its path. The water from the melted snow transformed the pyroclastic flow into a highly fluid lahar that followed the path of the May 19-20 lahar and rushed 15 miles $(24 \mathrm{~km})$ down Lost Creek nearly to Old Station. This new lahar again released a large volume of water that once again flooded lower Hat Creek. 


\section{STAGES OF THE 1914-1917 ER UP TION S OF LAS SEN PEAK}

May 30, 1914, to mid May 1915:

Steam explosions blasted a crater at the summit of Lassen Peak.

\section{Mid-May 1915:}

Small lava dome filled the new crater; late in the evening of May 19, a large explosion disrupted the dome, generating an avalanche and mudflow; the reopened vent erupted a lava flow.

\section{Afternoon of May 22, 1915:}

A vigorous eruption of pumice and ash formed a vertical eruption column that collapsed to initiate a hot pyroclastic flow and mudflow; continued fallout of hot pumice on snow generated additional mudflows; wind spread ash fallout to the northeast.

\section{May 1917:}

Renewed steam explosions blasted a new crater; vigorous steaming continued into the 1920 s and waned over the next few decades.
The Lassen volcano awoke on May 30, 1914, when steam explosions blasted out a small crater at the summit of Lassen Peak. Wisps of steam seen at the edges of the crater were typical between explosions. Knoll on right skyline is the actual summit of Lassen Peak, a 27,000-year-old dacite dome. Dark area in lower left is ashcovered snow. Middleground is covered with ash and rocks blasted out of the crater, whose wall shows such material to already be several feet thick. In this photograph taken by B.F. Loomis on June 20,1914, the crater is about 250 feet $(75 \mathrm{~m})$ long; it eventually grew to about 1,000 feet $(300 \mathrm{~m})$ by mid May of 1915 .

Michael A. Clynne,

eruption like that of Mount St. Helens in $1980\left(0.24\right.$ cubic mile or $\left.1 \mathrm{~km}^{3}\right)$. The deposits from the Lassen Peak eruptions are rapidly becoming obscured by vegetation and erosion, and the small size and unconsolidated nature of the thin deposits make the 1915 eruptions unlikely to be preserved in the long-term geologic record. Today, Lassen Peak sleeps again, but active steam vents, hot springs, and bubbling mudpots are still found elsewhere in Lassen Volcanic National Park.

No one can say when, but it is almost certain that the Lassen area will experience volcanic eruptions again. The USGS California Volcano Observatory operates a sophisticated sensor network to detect any increase in seismicity, ground deformation, or gas emissions that could indicate magma rising toward the surface in preparation for the next Lassen eruption. Early detection of such eruption precursors is essential to effective hazard mitigation and forecasting. The work of USGS scientists at Lassen is only part of the USGS Volcano Hazards Program's ongoing efforts to protect people's lives and property in all of the volcanic regions of the United States.
Robert L. Christiansen,

Peter H. Stauffer, James W. Hendley II, and Heather Bleick

Graphics and layout by Jeanne S. DiLeo

COOPERATING ORGANIZATIONS

Lassen Association

National Park Service

U.S. Forest Service

For more information contact: U.S. Geological Survey

California Volcano Observatory http://volcanoes.usgs.gov/observatories/calvo/

This fact sheet and any updates to it are available online at http://pubs.usgs.gov/fs/2014/3119

For more of the geologic history of the Lassen region, see Volcano hazards of the Lassen Volcanic National Park area, California (USGS Fact Sheet 022-00); How old is "Cinder Cone"?-Solving a mystery in Lassen Volcanic National Park, California (USGS Fact Sheet 023-00); and "Hot water" in Lassen Volcanic National Park_Fumaroles, steaming ground, and boiling mudpots (USGS Fact Sheet 101-02). eruptions was approximately 0.007 cubic mile $\left(0.03 \mathrm{~km}^{3}\right)$ - tiny compared to a major 